Jurnal Indah Sains dan Klinis, Volume 2 No.3 (2021): 31-39

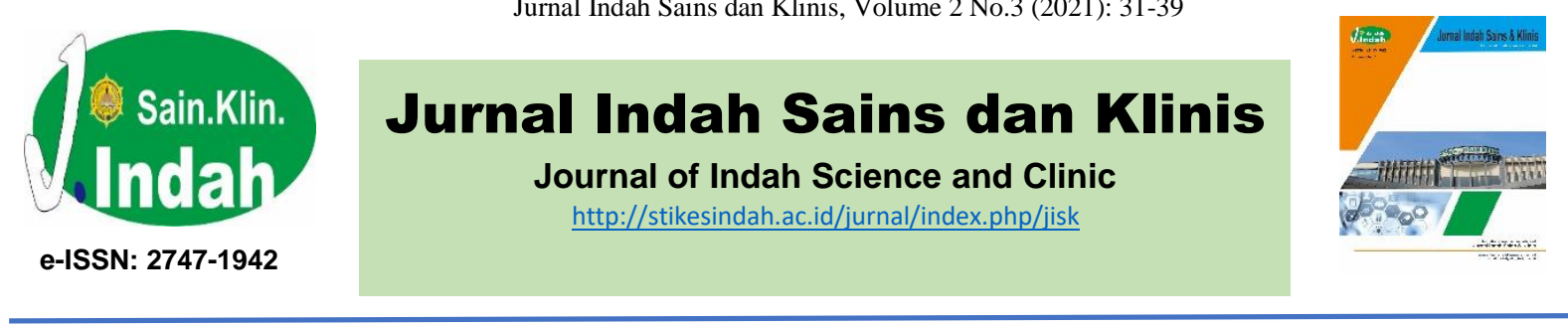

\title{
Pendidikan Kesehatan tentang Pengobatan pada Pasien Tuberculosis Paru di Rumah Sakit Tk II Putri Hijau Medan Tahun 2021
}

\author{
Doni Hariansyah $^{1)}$, Deni Susyanti' ${ }^{2}$, Muchti Yuda Pratama ${ }^{3)}$ \\ Akademi Keperawatan Kesdam I/BB Medan, email: donihariansyah126@gmail.com \\ *Corresponding author: Deni_susyanti@yahoo.com
}

Received: 24 Oktober 2021; Revised: 29 Nopember 2021; Accepted: 1 Desember 2021

DOI: $10.52622 /$ jisk.v2i3.37

\begin{abstract}
Tuberculosis is direct infectious disease caused by mycobacterium tuberculosis which transmitted through the air (droplet nuclei) when a patient with tuberculosis cough and the saliva droplets that containing the bacteria were inhaled by another person while breathing. The period of treatments for pulmonary tuberculosis required complete adherence. Irregular treatment is caused by the habit that the patient already felt healthy and does not spend the drugs completely and also the side effects of the drugs that make the patient unable to stand it then stop taking the drugs.There were some reasons that lead to the resistance pulmonary tuberculosis bacteria to OAT or MDR-TB. The knowledge management for uneducated patients is needed by providing health education about the treatment of tuberculosis.Methods: The study used descriptive study by involving nursing process which include of assessment, diagnosis, intervention, implementation and evaluation on two patients with pulmonary tuberculosis at TK II Putri Hijau Hospital Medan. Results: It was obtained that the lack of knowledge problem could be resolved in patient I while in patient II the problem was partially resolved.
\end{abstract}

Keywords : Health Education, Lack of Knowledge, Pulmonary Tuberculosis.

\begin{abstract}
ABSTRAK
Tuberculosis merupakan penyakit menular langsung yang disebabkan oleh mycobacterium tuberculosis yang ditularkan melalui udara (droplet nuklei) saat pasien tuberculosis batuk dan percikan ludah yang mengandung bakteri tersebut terhirup oleh orang lain saat bernapas. Melihat lamanya pengobatan tuberculosis paru diperlukan kepatuhan pengobatan hingga tuntas. Pengobatan yang tidak teratur dikarenakan kebiasaan pasien merasa badannya sudah sehat sehingga tidak menghabiskan obat dan juga efek samping dari obat tersebut yang membuat pasien tidak tahan dan menghentikan minum obat. Beberapa hal tersebut yang menyebabkan timbulnya resistensi kuman tuberculosis paru terhadap OAT secara meluas atau MDR-TB. Penatalaksanaan untuk kurang pengetahuan ini adalah memberikan pendidikan kesehatan tentang pengobatan pada pasien tuberculosis paru. Metode penelitian ini bersifat penelitian deskriptif dengan menggunakan pendekatan proses keperawatan yang meliputiPengkajian, Diagnosis Keperawatan, Intervensi Keperwatan, Implementasi Keperawatan dan Evaluasi Keperawatan pada dua klien penyakit tuberculosis Paru di Rumah Sakit TK II Putri Hijau Medan. Berdasarkan hasil yang didapatkan pada pasien I masalah kurang pengetahuan dapat teratasi sedangkan pada pasien II masalah kurang pengetahuan teratasi sebagian.
\end{abstract}

Kata kunci: Pendidikan Kesehatan, Kurang Pengetahuan, Tuberculosis Paru 


\section{PENDAHULUAN}

Tuberculosis merupakan penyakit menular langsung yang disebabkan oleh mycobacterium tuberculosis yang ditularkan melalui udara (droplet nuklei) saat pasien tuberculosis batuk dan percikan ludah yang mengandung bakteri tersebut terhirup oleh orang lain saat bernapas. Penderita tuberculosis akan mengalami tanda dan gejala seperti berkurangnya berat badan, demam, keringat dingin, mudah lelah, kehilangan nafsu makan, batuk, sputum berdarah, nyeri dada, sesak nafas (1).

Menurut laporan World Health Organization tahun 2016, pengobatan terhadap penyakit tuberculosis telah menghindari 49 juta kematian di seluruh dunia. Di seluruh dunia, penyakit tuberculosis merupakan salah satu ancaman kesehatan masyarakat yang utama sebagai penyebab kematian akibat penyakit menular. Asia Tenggara dengan 5 dari 22 negara yang memiliki beban tuberculosis tertinggi di dunia. Sebanyak 35\% seluruh kasus tuberculosis paru di dunia berada di kawasan ini.

Indonesia pada tahun 2016 terdapat tiga provinsi dengan jumlah kasus tuberculosis tertinggi yaitu provinsi Jawa Barat, Jawa Timur dan Jawa Tengah. Jawa Tengah adalah salah satu provinsi dengan kasus tuberculosis paru tertinggi di Indonesia. Jumlah seluruh kasus tuberculosis di Jawa Tengah pada tahun 2016 sebanyak 35.743 kasus merupakan 13,7\% terhadap kasus tuberculosis paru nasional (2).

Angka keberhasilan pengobatan (success rate) rata-rata ditingkat provinsi mencapai $92,19 \%$, dengan perincian persentase kesembuhan 85,52\%, namun hal ini mengalami kenaikan sebesar 2,58\% dibandingkan tahun 2015 (89,61\%). Angka success rate pada tahun 2016 ini telah mampu melampaui target nasional yaitu 85\%. Dari $33 \mathrm{Kab} / \mathrm{Kota}$ terdapat 2 $\mathrm{Kab} /$ Kota yang belum mampu mencapai angka success rate $85 \%$ antara lain Medan \& Padang Sidempuan (3).

Jumlah pasien tuberculosis paru dengan bakteri tahan asam (BTA) positif sebesar 3.087 penderita tuberculosis paru, hal ini dikarenakan waktu pengobatan yang panjang dengan jenis obat lebih dari satu menyebabkan penderita sering terancam putus berobat selama penyembuhan dengan berbagai alasan (4).

Melihat lamanya pengobatan tuberculosis paru diperlukan kepatuhan pengobatan hingga tuntas. Pengobatan yang tidak teratur dikarenakan kebiasaan pasien merasa badannya sudah sehat sehingga tidak menghabiskan obat dan juga efek samping dari obat tersebut yang membuat pasien tidak tahan dan menghentikan minum obat. Beberapa hal tersebut yang menyebabkan timbulnya resistensi kuman tuberculosis paru terhadap OAT secara meluas atau MDR-TB (5).

Faktor pengetahuan pasien tentang penyakit ataupun pengobatan berpengaruh terhadap kepatuhan penggunaan obat tuberculosis paru sehingga dampaknya dapat terjadi multi drug resistant terhadap obat tuberculosis paru (5).

Hhubungan yang signifikan antara tingkat pengetahuan dengan kepatuhan penderita tuberculosis paru. Semakin baik tingkat penggetahun penderita terhadap penyakit, cara penularan dan pengobatan tuberculosis paru maka akan semakin baik pula kepatuhan yang dimiliki dan begitu pula sebaliknya dan sebaiknya penderita di berikan pendidikan kesehatan yang adekuat terutama terkait pentingnya kepatuhan dalam menjalani terapi (6).

Tindakan atau peran petugas di rumah sakit selama memberikan pelayanan kesehatan keapda penderita tuberculosis paru sangatlah penting dalam memberikan informasi tentang pentingnya meminum obat secara teratur dan tuntas, menjelaskan mengenai aturan minum obat yang benar dan gejala efek samping yang mungkin dialami pasien, kesedaiaan petugas mendengarkan keluhan pasien dan memberikan solusinya dan peran petugas dalam memberikan penyuluhan kesehatan kepada pasien (7). 
Berdasarkan survey pendahuluan yang peneliti lakukan di Rumah Sakit TK II Putri Hijau Medan pada bulan Oktober 2020 diperoleh data jumlah pasien rawat inap dengan diagnosa tuberculosis paru di Rumah Sakit TK II Putri Hijau Medan sebanyak 4 jiwa yang terdiri dari 3 laki-laki dan 1 perempuan.

Dari data diatas maka penulis tertarik untuk menyusun karya tulis ilmiah dalam bentuk pemenuhan kebutuhan pendidikan kesehatan terhadap kepatuahan minum obat pada pasien tuberculosis paru di Rumah Sakit Putri Hijau TK II Medan.

\section{METODE PENELITIAN}

Metode penelitian ini mencakup rancangan penelitian yang direncanakan untuk melakukan studi kasus.

Design Studi Kasus

Penelitian ini merupakan penelitian deskriptif dengan rancangan studi kasus pemenuhan kebutuhan pendidikan kesehatan tentang pengobatan pada pasien tuberculosis paru dengan menggunakan pendekatan proses keperawatan yang dilakukan peneliti meliputi tahapan sebagai berikut;

1. Pengkajian

Peneliti pengumpulan data secara auto dan alloanamnesa baik yang bersumber dari responden/pasien, keluarga pasien, maupun lembar status pasien.

2. Diagnosis keperawatan

Peneliti melakukan analisis terhadap semua data yang diperoleh sehingga didapatkan diagnosa keperawatan yang diangkat yaitu gangguan pola tidur.

3. Intervensi keperawatan

Peneliti menyusun rencana tindakan keperawatan untuk mengatasi masalah keperawatan yang terjadi yaitu memberi pendidikan kesehatan tentang pengobatan pada pasien tuberculosis paru .

4. Implementasi keperawatan

Peneliti melakukan rencana tindakan yang telah disusun.

5. Evaluasi keperawatan

6. Peneliti melakukan penilaian tindakan keperawatan yang telah dilakukan dalam mengatasi masalah yang terjadi.

\section{Subyek Penelitian}

Subjek yang digunakan adalah 2 pasien dengan 1 kasus dengan masalah keperawatan yang sama. Studi kasus berjudul pendidikan kesehatan tentang pengobatan pada pasien tuberculosis Paru.

Adapun kriteria inklusi dan eksklusi pada penelitian ini adalah :

\section{Kriteria Inklusi:}

1. Penderita tuberculosis paru yang bersedia menjadi responden

2. Penderita tuberculosis paru dengan jenis kelamin laki-laki.

3. Penderita tuberculosis paru dengan umur $>30$ tahun

Kriteria ekslusi :

1. Penderita tuberculosis paru memiliki komplikasi

2. Penderita tuberculosis paru yang tidak bersedia menjadi responden.

Fokus Studi

1. Studi kasus ini terfokus pada pemenuhan kebutuhan pendidikan kesehatan terhadap kepatuhan minum obat pada pasien tuberculosis paru.

2. Lama hari perawatan selama 3 hari pada pasien tuberculosis paru dalam pemenuhan kebutuhan istirahat tidur pada pasien tuberculosis paru. 
Identitas dan Hasil Anamnesa

Tabel 4.4 Identitas dan Hasil Anamnesa

\begin{tabular}{|c|c|c|c|}
\hline No & Identitas Pasien & Kasus I & Kasus II \\
\hline 1. & Diagnosa Medis & Tuberculosis Paru & Tuberculosis Paru \\
\hline 2. & Nama & Tn. A & Tn. R \\
\hline 3. & Umur & 28 Tahun & 58 Tahun \\
\hline 4. & Jenis Kelamin & Laki-laki & Laki-laki \\
\hline 5. & Pendidikan & SMA sederajat & SMA sederjat \\
\hline 6. & Pekerjaan & TNI-AD & Wiraswasta \\
\hline 7. & Status & Menikah & Menikah \\
\hline 8. & Agama & Islam & Kristen \\
\hline 9. & Suku bangsa & Jawa & Batak \\
\hline 10. & Bahasa & Indonesia & Indonesia \\
\hline 11. & Alamat & $\begin{array}{l}\text { Asmil Yon Arhanudse } \\
\text { Medan }\end{array}$ & $\begin{array}{l}\text { Jl. Pembangunan } \\
\text { Helvetia }\end{array}$ \\
\hline 12. & Ditanggung oleh & BPJS & BPJS \\
\hline 13. & $\begin{array}{l}\text { Tanggal dan jam masuk RS } \\
\text { (IGD) }\end{array}$ & $\begin{array}{l}\text { 03 Mei } 2021 \\
\text { Pukul : } 08.15 \text { WIB }\end{array}$ & $\begin{array}{l}\text { 06 Mei } 2021 \\
\text { Pukul : } 11.35 \text { WIB }\end{array}$ \\
\hline 14. & Tanggal dan jam masuk ruangan & $\begin{array}{l}\text { 03 Mei } 2021 \\
\text { Pukul : } 09.35 \text { WIB }\end{array}$ & $\begin{array}{l}\text { 06 Mei } 2021 \\
\text { Pukul : } 13.00 \text { WIB }\end{array}$ \\
\hline 15. & Tanggal dan jam pengkajian & $\begin{array}{l}\text { 03 Mei } 2021 \\
\text { Pukul : } 14.30 \text { WIB }\end{array}$ & $\begin{array}{l}06 \text { Mei } 2021 \\
\text { Pukul : } 16.00 \text { WIB }\end{array}$ \\
\hline
\end{tabular}

Berdasarkan tabel 4.4 didapatkan dari kedua responden berjenis kelamin laki-laki dan mempunyai diagnosis yang sama yaitu tuberculosis paru. Pada kasus I dengan pasien berumur 28 tahun dan kasus II dengan pasien berumur 58 tahun.

\section{Data Fokus}

Tabel 4.5 Keluhan Utama dan Riwayat Sakit

\begin{tabular}{|c|c|c|c|}
\hline No & Data Fokus & Kasus I & Kasus II \\
\hline 1. & $\begin{array}{l}\text { Keluhan utama saat masuk } \\
\text { rumah sakit }\end{array}$ & $\begin{array}{l}\text { Sesak } \pm 2 \text { hari, demam, batuk, } \\
\text { cegukan terus menerus, }\end{array}$ & $\begin{array}{l}\text { Lemas, batuk darah } \pm 2 \\
\text { minggu, sesak }\end{array}$ \\
\hline 2. & $\begin{array}{l}\text { Keluhan utama saat } \\
\text { pengkajian }\end{array}$ & $\begin{array}{l}\text { Cegukan terus menerus, } \\
\text { menggigil, sesak,demam }\end{array}$ & Lemas, batuk berdahak \\
\hline 3. & Riwayat penyakit sekarang & Tuberculosis Paru & Tuberculosis Paru \\
\hline 4. & Riwayat kesehatan yang lalu & Tuberculosis paru & Tuberculosis Paru \\
\hline 5. & Riwayat keluarga & $\begin{array}{llr}\text { Klien merupakan seorang } \\
\text { tentara yang bertugas di } \\
\text { siantar, mempunyai dua orang } \\
\text { anak } 1 \text { laki-laki dan } 1 \\
\text { perempuan kandung dan } 1 \\
\text { orang istri }\end{array}$ & $\begin{array}{l}\text { Klien seorang } \\
\text { pedagang sayuran, } \\
\text { memliki 5 orang anak } \\
3 \text { laki-laki dan 2 } \\
\text { perempuan serta } \\
\text { memiliki 1 orang istri. }\end{array}$ \\
\hline 6. & Kebiasaan & Merokok & Merokok \\
\hline
\end{tabular}

Berdasarkan tabel 4.5 ditemukan keluhan utama dan riwayat penyakit terhadap kasus I yaitu klien mengatakan sesak nafas \pm 2 hari, demam, batuk, cegukan terus menerus dan riwayat penyakit terdahulu adalah tuberculosis paru \pm 1 tahun yang lalu. Sedangkan klien dengan kasus II ditemukan keluhan utama dan riwayat penyakit yaitu lemas, batuk darah \pm 2 minggu, sesak dan riwayat penyakit terdahulu adalah tuberculosis paru \pm 1 tahun yang lalu. 


\section{Analisa Data}

Berdasarkan tabel 4.8 hasil analisa data di atas bahwa pada kasus I mengalami masalah kurang pengetahuan yang berhubungan dengan kurang terpajan informasi karena keterbatasan kognitif dan tak lengkap informasi yang ada ditandai dengan klien tampak tidak teratur minum obat, klien tampak malas meminum obat, klien tampak bosan untuk meminum obat, klien tampak tidak mmeperhatikan obatnya, klien tampak sering menyembunyikan obatnya di bawah tempat tidur, istri klien tampak tidak peduli ketika suaminya minum obat.

Sedangkan kasus II mengalami masalah kurang pengetahuan yang berhubungan dengan kurang terpajan informasi karena keterbatasan kognitif dan tak lengkap informasi yang ada di tandai dengan klien tampak tidak teratur meminum obatnya, klien tampak tidak tau jika penyakitnya dapat berulang, klien tampak malas untuk minum obat, klien tampak kurang mengerti tentang pengobatannya, klien tampak menolak jika disuruh minum obat.

\section{Diagnosa Keperawatan}

\begin{tabular}{llll}
\hline \multicolumn{3}{c}{ Kasus I } & \multicolumn{3}{c}{ Kasus II } \\
\hline Kurang pengetahuan berhubungan dengan & Kurang pengetahuan berhubungan dengan \\
kurang terpajan informasi & karena & kurang terpajan informasi karena \\
keterbatasan kognitif dan tak lengkap & $\begin{array}{l}\text { keterbatasan kognitif dan tak lengkap } \\
\text { informasi }\end{array}$ & & informasi
\end{tabular}

\section{Pembahasan}

Pada pembahasan ini, peneliti akan membahas " Asuhan keperawatan pada pasien tuberculosis paru dengan pemenuhan kebutuhan pendidikan kesehatan di Ruang Isolasi”. Penelitian ini telah dilaksanakan paa kasus I 03 Mei 2021 sampai dengan 05 Mei 2021 dan kasus II pada tanggal 06 Mei 2021 sampai 08 Mei 2021. Dalam hal ini pembahasan yang dimaksud adalah membandingkan antara tinjauan kasus dengan tinjauan pustaka yang disajikan untuk menjawab tujuan khusus dari penelitian. Dimana setiap temuan perbedaan diuraikan dengan konsep dan pembahasan disusun dengan tujuan khusus.

Peneliti melakukan penelitian terhadap dua partisipan yang sama-sama memiliki penyakit tuberculosis paru di Ruang Isolasi Rumah Sakit TK II Putri Hijau Medan dengan lima tahap sesuai dengan proses keperawatan yang dikembangkan oleh American Nurse Association yaitu pengkajian, diagnosa keperawatan, intervensi keperawatan, implementasi keperawatan dan evaluasi. Asosiasi Diagnosa Keperawatan Amerika (NANDA) kemudian mengembangkan dan mengelompokkan diagnosa keperawatan serta membantu menciptakan pola komunikasi antar perawat dan dapat memberikan batasan antara diagnosa keperawatan dengan diagnosa medis. Diagnosa keperawatan berfokus pada respon klien, sedangkan diagnosa medis berfokus pada proses penyakitya(8). Tujuan khusus tersebut meliputi menggali pengkajian keperawatan, menyusun perencanaan asuhan keperawatan, merumuskan diagnosa keperawatan, melakukan implementasi yang komprensif, serta melakukan evaluasi keperawatan. Berikut adalah pembahasan yang disesuaikan dengan tujuan khusus dari penelitian tersebut.

\section{Pengkajian}

Berdasarkan tabel 4.4 didapatkan dari kedua partisipan mempunyai diagnosa medis yang sama yaitu tuberculosis paru yang didasarkan pada kasus I didapatkan data klien tidak teratur dalam minum obat, malas minum obat karena tidak ada istrinya didekatnya dan mengaku bosan untuk minum obat. Sedangkan pada kasus II didapatkan data klien tidak teratur minum obat karena aktifitasnya, tidak mengetahui penyakitnya dapat berulang kembali jika tidak teratur minum obat dan malas untuk minum obatnya karena terlalu banyak obat yang diminum.

Klien yang tidak didampingi PMO terdapat 26,3\% patuh dan 21,2\% tidak patuh (drop out) pada fase intensif. Sedangkan klien yang didampingi PMO terdapat $82,1 \%$ patuh dan 3,6\% tidak patuh. Ketidakpatuhan berobat pada fase intensif dikarenakan klien merasa bosan dan mual pada saat minum obat setiap harinya, ada juga yang memberi alasan bahwa dirinya merasa sembuh(9). 
Berdasarkan tabel 4.4 hasil pengkajian kedua partisipan memiliki beberapa kesamaan yaitu berdasarkan Tabel 4.4 hasil pengkajian kedua partisipan memiliki kesamaan yaitu berjenis kelamin laki-laki dan memiliki kebiasaan yang buruk yaitu merokok pada kasus I berumur 49 tahun dan kasus II berumur 56 tahun.

Jumlah kejadian tuberculosis paru pada laki-laki lebih banyak dibandingkan dengan perempuan. Hal ini disebabkan bahwa laki-laki sebagai kepala keluarga yang lebih banyak beraktivitas diluar rumah sehingga mudah untuk tertular tuberculosis paru.

Berdasarkan tabel 4.4 didapat perbedaan pekerjaan pada kasus I memiliki pekerjaan TNI-AD dan kasus II memiliki pekerjaan wiraswasta. Menurut Fitria. (2017), jumlah kejadian pada tuberculosis paru paling banyak pada pekerjaan sebagai wiraswasta, petani, nelayan, buruh pabrik merupakan jenis pekerjaan yang paling banyak dijumpai menderita tuberculosis paru.

Berdasarkan tabel 4.5 dari hasil pengkajian memiliki kesamaan yaiu kedua partisipan yaitu mengalami batuk berdahak, pada kasus I mengalami batuk berdahak dan pada kasus II mengalami batuk disertai darah 2 minggu.

Menurut Mardiono (2013), penderita tuberculosis paru akan mengalami tanda dan gejala seperti berkurangnya berat badan, demam, keringat, mudah lelah, kehilangan nafsu makan, batuk, sputum berdarah, nyeri dada, sesak napas.

Berdasarkan tabel 4.9 didapatkan kedua pasien yaitu kasus I dan kasus II memiliki diagnosa medis serta diagnosa keperawatan yang sama yaitu tuberculosis paru dengan diagnosa keperawatan kurang pengetahuan berhubungan dengan kurang terpajan informasi karena keterbatasan kognitif dan tak lengkap informasi. Terdapat data yang memperkuat untuk menegakan diagnosa keperawatan lebih difokuskan pada pengakajian yaitu kedua partisipan mengalami tuberculosis paru yang berulang karena tidak teratur untuk minum obat.

Ada beberapa faktor yang dapat mempengaruhi tingkat kepatuhan sesorang untuk minum obat, yaitu antara lain usia, pekerjaan, waktu luang, pengawasan, jenis obat, dosis obat, penyuluhan dari petugas kesehatan dan pengetahuan sikap menjadi faktor kepatuhan seseorang dalam minum obat(10).

\section{Rencana Keperawatan}

Berdasarkan tabel 4.10 didapatkan dari kedua partisipan keduanya mempunyai rencana tindakan keperawatan yang sama dari rumah sakit di ruang isolasi Rumah Sakit TK II Putri Hijau Medan. Rencana tindakan keperawatan di Rumah Sakit TK II Putri Hijau Medan hampir sama dengan rencana keperawatan yang ada pada teori Dongoes, yang beda peneliti mempunyai intervensi untuk melakukan pengenalan obat-obatan untuk pasien yang terkena penyakit tuberculosis paru(11).

\section{Tindakan Keperawatan}

Tindakan keperawatan yang sama dengan rencana di teori Dongoes tindakan keperawatan yang dilakukan untuk kedua respoden sesuai dengan rencana tindakan di Rumah Sakit TK II Putri Hijau Medan(11). Peneliti tidak melakukan pengenalan jenis obat-obatan yang harus dikonsumsi pasien karena pasien tidak mendapatkan obat-obatan yang seharusnya dikonsumsi oleh pasien TB Paru karena klien telah melakukan DOTS selama 6 bulan tetapi tidak berhasil yang menyebabkan pasien kembali dirawat dan akan diberikan lagi DOTS setelah pasien selesai dirawat. Selama dirawat pasien hanya diberikan extra antibiotic saja.

Padahal seharusnya kedua klien harus mendapatkan terapi obat anti tuberculosis yang sebagaimana dituangkan oleh Kementrian Kesehatan sudah membuat sebuah standar acuan bagi para tenaga kesehatan di unit-unit pelayanan kesehatan masyarakat di Indonesia dalam melaksanakan pengendalian dan pengobatan tuberculosis paru.

Kedua pasrtisipan merupakan pasien tuberculosis yang berulang dan sangat penting untuk mendapatakan terapi obat yang intensif untuk mengurangi resiko penularan penyakit. Pengobatan tuberculosis paru pada fase intensif, klien mendapat obat setiap hari dan perlu diawasi setiap hari dan bila dilakukan secara tepat maka klien tuberculosis paru menjadi tidak menular dalam kurun waktu 2 minggu dan sebagian besar klien tuberculosis paru BTA positif menjadi negative dalam waktu 2 bulan, sehingga klien tidak mengalami drop out dan pengobatan ulang(12).

\section{Evaluasi}


Pada diagnosa keperawatan kurang pengetahuan, setelah dilakukan tindakan keperawatan pada tanggal 03 Mei s/d 05 Mei 2021 pada kasus I dan tanggal 06 Mei s/d 08 Mei 2021 pada kasus II. Kedua responden tersebut memiliki respon yang berbeda pada saat dilakukan tindakan keperawatan.

Berdasarkan tabel 4.12 dari evaluasi diperoleh hasil yang berbeda antara kedua responden. Pada kasus I diperoleh pada hari pertama pada tanggal 03 Mei 2021 klien mengatakan mulai mengerti penyebab terjadi penyakit tuberculosis paru, klien bisa mengucapkan defenisi dari penyakitnya, klien mengatakan kurang paham akan penyakitnya dana penyebabnya.

Hasil evaluasi hari kedua pada tanggal 04 Mei 2021 klien sudah bisa mengucapkan kembali dengan pasih penyebab dan pengertian tuberculosis paru, klien sedikit mengetahui tentang penyebab serta cara pencegahan penyakit tuberculosis paru, klien mengatakan belum mengetahui tentang pengobatan tuberculosis paru. Hasil evaluasi hari ketiga pada tanggal 05 Mei 2021 klien bisa mengulangi semua materi yang diberikan oleh perawat, klien sudah mengerti tentang penyakitnya, khususnya tentang pengobatan klien.

Sedangkan pada kasus II pada tanggal 06 Mei 2021 klien mengatakan akan meluangkan waktunya untuk minum obat meskipun sibuk, klien mengatakan belum mengerti tentang penyakitnya, klien mengatakan kurang paham akan pengobatan penyakit tuberculosis paru.

Hasil evaluasi hari kedua pada tanggal 07 Mei 2021 klien mengatakan mulai mengerti tentang penularan dan pencegahan penyakit tuberculosis paru, klien mengatakan sedikit mengerti tentang penyebab tuberculosis paru, klien tampak tidak memberikan perhatiannya ke peneliti. Hasil evaluasi hari ketiga pada tanggal 08 Mei 2021 klien hanya mampu menyebutkan definisi serta penularan penyakit tuberculosis paru, klien tampak susah untuk menyebutkan tentang pengobatan serta pencegahan penyakit tuberculosis paru

Maka dapat disimpulkan evaluasi hari terakhir pada kedua responden berbeda pada kasus I evaluasi akhir masalah kurang pengetahuan teratasi sedangkan pada kasus II evaluasi akhir masalah kurang pengetahuan sebagian teratasi sehingga dilanjutkan oleh perawat ruangan.

Dari hasil yang didapatkan pada pasien I masalah kurang pengetahuan dapat teratasi sedangkan pada pasien II masalah kurang pengetahuan teratasi sebagian. Ini dapat disebabkan sebagaimana dijelaskan di teoritis keperawatan bahwa faktor usia bisa menyebabkan terjadinya kurang pengetahuan tentang pengobatan pada pasien tuberculosis paru.

\section{KESIMPULAN DAN SARAN \\ Kesimpulan}

Setelah peneliti melakukan asuhan keperawatan pada pasien tuberculosis paru dengan pemenuhan pendidikan kesehatan terhadap kepatuhan minum obat di ruang Isolasi Rumah Sakit TK II Putri Hijau Medan pada kasus I tanggal 03 Mei s/d 05 Mei 2021 dan pada kasus II tanggal 06 Mei 2021 s/d 08 Mei 2021 didapatkan hasil:

\section{Pengkajian}

Didapatkan hasil pengkajian dari kedua partisipan yaitu pada kasus I mengalami sesak \pm 2 hari, demam, batuk, cegukkan terus menerus. Sedangkan kasus II mengalami lemas, batuk darah \pm 2 minggu, sesak

\section{Diagnosa Keperawatan}

Berdasarkan dari diagnosa keperawatan didapatkan hasil kedua partisipan memiliki diagnosa keperawatan yang sama yaitu kurang pengetahuan berhubungan dengan kurang terpajan informasi karena keterbatasan kognitif dan tidak lengkap informasi.

\section{Rencana Tindakan Keperawatan}

Hasil dari rencana tindakan keperawatan yang telah dilakukan yaitu kedua responden memilki rencana tindakan yang sama sesuai dengan SOP rencana tindakan yang ada di Rumah Sakit TK II Putri Hijau Medan. Peneliti memiliki rencana tindakan yang berbeda dengan ruangan yaitu memperkenalkan obat-obatan yang harus diminum oleh pasien

\section{Tindakan Keperawatan}


Tindakan keperawatan yang dilakukan kepada kedua partisipan sama sesuai dengan rencana tindakan yang ada di ruang Isolasi di Rumah Sakit TK II Putri Hijau Medan. Peneliti tidak melakukan rencana tindakan keperawatan memperkenalkan kembali obat-obatan yang harus diminum klien karena klien tidak mendapatkan obat tersebut di ruangan dengan alasan klien telah dilakukan DOTS selama 6 bulan tetapi tidak berhasil yang menyebabkan klien masuk kembali ke rumah sakit.

\section{Evaluasi}

Pada hasil evaluasi antara kedua partisipan didapatkan hasil yang berbeda. Pada kasus I masalah kurang pengetahuan klien telah teratasi sedangkan pada kasus II masalah kurang pengetahuan sebagian teratasi dan intervensi dilanjutkan oleh perawat ruangan.

\section{Saran}

1. Bagi Rumah Sakit, sebaiknya menyediakan sarana dan prasarana yang lengkap dan baik guna membantu dalam melaksanakan asuhan keperawatan sehingga rasa puas bagi keluarga pasien.

2. Bagi Pengembangan Ilmu Dan Teknologi Keperawatan. Pengembangan ilmu dan teknologi keperawatan hendaknya menambah keluasan ilmu dan teknologi dalam bidang keperawatan terutama pemenuhan kebutuhan pendidikan kesehatan terhadap kepatuhan minum obat pada pasien tuberculosis paru. Karena obat yang teratur adalah kunci dari keberhasilan pengobatan pasien tuberculosis paru.

3. Bagi Klien dan Keluarga diharapkan selalu memperhatikan program pengobatan yang dilakukan dengan cara saling memperhatikan untuk jadwal minum obat klien. Supaya pengobatan klien dapat dilakukan dengan benar dan berhasil dalam pengobatannya.

\section{UCAPAN TERIMAKASIH}

Terima kasih kepada Seluruh Dosen dan Staff di Akademi Keperawatan Kesdam I/BB Medan yang telah membimbing serta membekali ilmu selama penulis mengikuti pendidikan di Akademi Keperawatan Kesdam I/BB Medan.

\section{DAFTAR PUSTAKA}

1. Mardiono S (2013). Pengaruh Latihan Batuk Efektif terhadap Frekuensi Pernapasan Pasien TB Paru di Instalasi Rawat Inap Penyakit dalam Rumah Sakit Pelabuhan Palembang Tahun 2013. J Harapan Bangsa. 2013;1(2).

2. Badan Penelitian dan Pengembangan Kesehatan. Riskesdas 2018. Badan Penelitian dan Pengembangan Kesehatan. 2018.

3. Pratama MY, Gurning FP, Suharto S. Implementasi Penanggulangan Tuberkulosis di Puskesmas Glugur Darat Kota Medan. J Kesmas Asclepius. 2019;1(2).

4. Alexa. Hubungan Tingkat Pengetahuan Dengan Kepatuhan Pada Pengobatan Penderita Tuberculosis Paru. J Keperawatan [Internet]. 2020;4(2):13-5. Available from: https://cholar.google.co.id

5. Devi. Faktor-Faktor Yang Berhubungan Dengan Perilaku Pasien TB MDR Dalam Pencegahan Penularan TB MDR Di Wilayah Kerja Puskesemas Kota Semarang. J Kesehat Masy. 2019;7(1).

6. Ariyani. Hubungan Tingkat Pengetahuan Dengan Kepatuhan Pada Pengobatan Penderita Tuberculosis Paaaru Di Puskesmas Pekauman Kota Banjarmasin, Kalimantan Selatan. J Pharm [Internet]. 2016;3(2):23-8. Available from: https://jps.unlam.ac.id

7. Pameswari. Tingkat Kepatuhan Penggunaan Obat Pada Pasien Tuberculosis di Rumah Sakit Mayjen H. A. Thalib Kabupaten Kerinci. J Sains Farm Klin [Internet]. 2016;2(2):116-21. Available from: http://jsfkonline.org

8. Tim T and. Anatomi dan Fisiologi. Jakarta; 2011.

9. Natalya. Perbedaan Kepatuhan Berobat Pada Penderita TB Paru yang Didampingi PMO dan Tidak Didampingi PMO di Wilayah Puskesmas Kabupaten Boyolali, jurnal ilmu kesehatan. J ilmu Kesehat [Internet]. 2016;1(2). Available from: http://jurnal.stikesmukla.ac.id/index.php/motor/article/view/242

10. Bagiada. Faktor-Faktor Yang Mempengaruhi Tingkat Ketidak Patuhan Penderita Tuberkulosis Dalam Berobat Di Poliklinik DOTS RSUP Sanglah Denpasar. J Penyakit Dalam. 2010;11(4). 
11. Doengoes ME. Doen. In: Rencana Asuhan Keperawatan. Jakarta; 2012.

12. RI KK. Rencana Strategis Kementrian Kesehatan Tahun 2015-2019. 2015; 